FACTA UNIVERSITATIS

Series: Physical Education and Sport, Vol. 16, No 2, 2018, pp. 309 - 318

https://doi.org/10.22190/FUPES180722027C

Research article

\title{
NUTRITIONAL LEVELS AND SPINE CURVATURE DISORDERS AMONG PRESCHOOL CHIDLREN
}

\author{
UDC 616.711:613.25-053.4
}

\author{
Nebojša Cvetković ${ }^{1}$, Jovana Cvetković \\ ${ }^{1}$ High School for Communications, Belgrade, Serbia \\ ${ }^{2}$ Preschool Institution "Spartak", Belgrade, Serbia
}

\begin{abstract}
The modern way of life led to the emergence of hypokinesis, obesity or various conditions and spine curvature disorders which are more and more present among younger children. The aim of this research was to determine the connection between nutritional levels and kyphosis and lordosis among preschool children. The sample of participants included of 50 boys and girls, preschoolers aged 6 to 7, who attend the Jelica Obradovic Preschool in Mladenovac. Previous approval was obtained from their parents and teachers for participation in this study. To evaluate nutritional levels, the body mass index was used, which divided the participants into four categories: underweight, normal weight, overweight and obese. Somatoscopy was used to evaluate posture, along with a wooden frame to which a net with square decimeters was attached. Based on the results of this test, the following variables were obtained: normal posture, poor posture, first level of severity and poor posture, second level of severity. To determine the connection, or possible influence of the nutritional levels on body posture, the Chi square test was used. The results indicate that there is no statistically significant connection between nutritional levels and kyphosis and lordosis for this group of preschool children. This could indicate that obesity and underweight do not influence the occurrence of spine curvature disorders independently, but probably in combination with other factors such as heredity, physical inactivity, etc.
\end{abstract}

Key words: kyphosis, lordosis, obesity, underweight, differences

\section{INTRODUCTION}

Poor posture includes not only one disorder, one specific deformity, but several disorders whose shared feature is that they are reversed with active tightening of the muscles. Poor posture is characterized by weakness in the entire body, especially the

Received July 22, 2018 / Accepted October 12, 2018

Corresponding author: Nebojsa Cvetkovic

High School for Communications, Bulevar Maršala Tolbuhina 36, 11070 Belgrade,, Sebia

Phone: +381 112604608 • E-mail: cvetkovic.nebojsa10@gmail.com 
joint-muscle apparatus. In these conditions, the static insufficiency of the spinal column is most pronounced, and is also the result of the weakness of the remaining parts of the locomotor apparatus (Živković, 2009).

The human movement apparatus is characterized by plastic adaptation, that is, the ability to relatively quickly adapt to changes in the mutual position of certain body parts. An analogous adaptational reaction in the muscles is also manifested in the change in their length. Due to long-term exposure of the muscles to a taut position, that is, their antagonists to a more relaxed position, a change occurs in the length and force of these muscles. If, after these changes, attempts were to be made to return the body parts to their previous interrelated positions by contracting the taut muscles, great resistance would be encountered. The factors which prevent the body parts from returning to their previous positions are, primarily, insufficient force of the atrophied muscles and the insufficient length of their antagonists, which is always accompanied by a shortening of the passive elements of the movement apparatus on the same side. Spine curvature disorders and body deformities, thus, are a consequence of the plastic adaptation of the movement apparatus, and their cause lies in the disruption of the balance between the tonic agonists and antagonists, which occurs due to relaxation in the musculature. Thus it is always necessary to remove the causes so as to avoid any undesired consequences (Perić \& Cvetković, 2003).

Experts claim that the posture of preschool and younger school age children has grown significantly poorer during the last few decades, and recent research (Protić-Gava, Šćepanović, \& Batez, 2013; Korovljev, Marinković, Roška, \& Madić, 2015; Đorđević, Jorgić, Milenković, Milenković, Đokić, \& Tsonkova, 2016) confirms these findings and indicates a progression in the spine curvature disorders of the aforementioned population. The basic cause of these disorders is ascribed to a single occurrence which is a result of the type of lifestyle that modern man leads, and in professional circles is known as hypokinesis. This way of life, dominated by passive stances, leads to changes in the motor behavior of children. This can best be seen during activities which are performed in a seated position, or standing position for longer periods of time, during which children usually assume inappropriate body positions. Thus the passive and active structures of the locomotor system, responsible for maintaining the normal upright position, are exposed to unnecessary load, which creates the conditions for the emergence of spine curvature disorders (Cvetković, 2014). In addition to hypokinesis, extensive or one-sided load, inactivity or weakness of muscle groups leads to spine curvature disorders, that is, disrupts the principle of symmetry and balance (Milenković, 2007).

According to Marković, Igrutinović, Kostić, and Vuletić (2008) nutritional levels represent a significant indicator of health and potential for normal growth and development, and can also be a good prognostic factor of one's state of health. Nutritional disorders among children can exceed or fail to reach the normal levels, which are evaluated by suitable methods. Disorders involving exceeding normal levels are referred to as obesity, and insufficient nutritional levels are known as underweight (Kostić, Gligorijević, \& Marković, 2001). In both cases, every excessive deviation from normal body weight can be an indicator of a health disorder or some pre-existing medical condition (Vlaški \& Katanić, 2010). According to Spiotta and Luma (2008), approximately one third of children under 19 are overweight. When it comes to children aged between 7 and 14 in Europe, 10 to 30\% of them are overweight (Steinberger et al., 2009). Since 1980, obesity has more than doubled, and obesity among children has increased two to four times in the last decade. The research 
results in our country also indicate a high number of preschool children who are obese, and they do differ significantly from the results obtained in other countries (Despotović, Alekxopulos, Despotović, \& Ilić, 2013). Based on the aforementioned, the aim of this research was to determine the extent of the correlations between nutritional levels and the kyphosis and lordosis among preschool children.

\section{METHODS}

\section{Sample of participants}

The sample of participants included of 50 boys and girls, preschoolers aged 6 to 7 , who attend the Jelica Obradović Preschool in Mladenovac. Previous approval was obtained from their parents and teachers for participation in this study.

\section{Sample of measuring instruments}

Measuring instruments for the evaluation of postural status in the sagittal plane, and for the evaluation of the nutritional level of the children, were used in this study.

\section{Measuring instruments for the evaluation of postural status in the sagittal plane}

Evaluating body posture was realized in two ways: visual observation of the participants (somatoscopy), and the body posture test. For a more precise visual equation, we used a special wooden frame, $(1,5 \mathrm{~m} \times 1 \mathrm{~m}$ in size) to which a net with square decimeters was attached (Figure 1). The body segments which were evaluated and based on which it was possible to determine the extent of possible deviations from the normal upright position were defined (Table 1). Based on the obtained values of the parameters, two variables stand out: kyphosis and lordosis, with the following levels of severity of the disorder:

1. Normal (physiological) posture (NP);

2. First level of severity (1LS);

3. Second level of severity (2LS).

The participants, wearing only their undergarments, were asked to assume a normal upright position, at a precisely determined place behind the frame, legs slightly apart, hands relaxed at their sides and eyes focused on a toy (a plush rabbit), which was placed at a distance of $2 \mathrm{~m}$, at eye level. The visual evaluation was performed in relation to the aforementioned frame (net), to determine the line of the body's center of gravity, whose orientation is vertically downward, and which passes through the following anatomic points: the middle ear, the center of the shoulder joint and the center of the hip joint, and any possible deviations from the body segments included in the established line.

A physical therapist, who was carrying out the evaluation, observed the participants from a distance of $1,5 \mathrm{~m}-2 \mathrm{~m}$. Through visual observation (somatoscopy) it was determined whether the participant has good or poor body posture. In the case of good posture, the participant was included in the category of normal physiological posture. If poor posture was determined based on the observed parameters, the participants was required to assume as proper a posture as possible, and as incentive a picture of a child with good body posture was shown. If the participant was able with the strength from his own 
muscles to maintain that position for 30 or more seconds, he was included in the category of the first level of severity. The participant who was not able to assume a proper standing position, or had managed to do so but did not maintain it for the required period of time, was included in the category of the second level of severity. This type of testing body posture has already been used in practice (Cvetković \& Perić, 2010).

Table 1 The list of studied parameters

\begin{tabular}{lll}
\hline Status of the spinal column in the saggital plane & Initial evaluation \\
\hline Name of the child: & NP $\quad$ 1LS $\quad 2 \mathrm{LS}$ \\
Body mass: & & \\
Height: & & \\
\hline Kyphosis & & \\
Head protrusion & \\
Slouching shoulders & \\
Inward concave thorax & \\
Abducted shoulder blades & \\
Lordosis & \\
Weakening of the abdominal wall & \\
Forward tilt of the pelvis \\
Pronounced lumbar lordosis \\
Shortened flexors of the hip joint
\end{tabular}

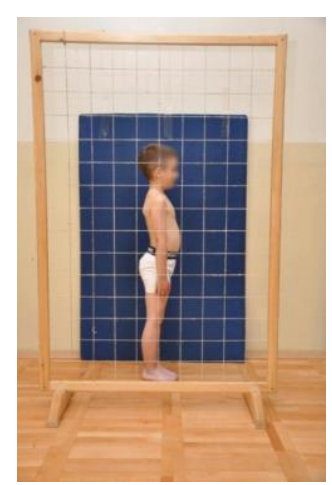

Fig. 1 The frame with the net use to evaluate posture

\section{Measuring instruments for the evaluation of the nutritional level}

The Body Mass Index (BMI) was used to evaluate the nutritional level. The formula used to calculate it is: $\mathrm{BM} / \mathrm{BH}^{2}$. Where $\mathrm{BM}$-is body mass expressed in kilograms and $\mathrm{BH}^{2}$-body height expressed in square meters (Garrow \& Webster, 1985). Body mass and height were determined using standard procedures which are used during physical examinations.

Based on the obtained BMI, individuals were classified into four categories:

1. Underweight (UW);

2. Normal weight $(\mathrm{NW})$;

3. Overweight $(\mathrm{OW})$;

4. Obesity (OB). 
In the case of children, in addition to the formula which is also used for adults, we also took into consideration both gender and year of birth. Then the obtained values were compared to a graph, separately for the males and females, to determine their percentiles (Kuczmarski et al., 2002). Based on those percentiles we determine the relative position of the child's BMI compared to children of the same age and gender (Table 2).

Table 2 The nutritional level in relation to percentiles

\begin{tabular}{ll}
\hline Nutritional level & Percentile range \\
\hline Underweight (UW) & Less than 5 \\
Normal weight (NW) & from 5 to less than 85 \\
Overweight (OW) & 85 to less than 95 \\
Obesity (OB) & 95 and over \\
\hline
\end{tabular}

\section{Statistical data analysis}

The data obtained on the nominal scale for the variables body posture and the body mass index are presented as frequencies and percentiles. To determine the correlations between the nutritional level and body posture in the sagittal plane we used the Chi square test. The data were processed in the statistical program IBM SPSS Statistics for Windows, Version 19.0. Armonk, NY: IBM Corporation, released in 2010.

\section{RESULTS}

The results presented in tables 3 indicates that many of the tested children show signs of kyphosis and lordosis, where spinal curvature of the first level of severity was recorded most frequently, with $44 \%$ and $52 \%$, respectively.

Table 4 shows the results for the evaluation of the body mass index. Most of the children $68 \%$ have normal weight. The lowest percentage of children showed signs of being underweight, $4 \%$, followed by the percentage of overweight children $6 \%$, and finally obese children $22 \%$.

Table 3 Prevalence of kyphosis and lordosis

\begin{tabular}{|c|c|c|c|c|c|c|}
\hline & $\cong$ & Frequency & $\begin{array}{c}\text { Percentage } \\
(\%)\end{array}$ & 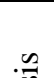 & Frequency & $\begin{array}{c}\text { Percentage } \\
(\%)\end{array}$ \\
\hline NP & 8 & 10 & 20 & o & 9 & 18 \\
\hline LS1 & $\overline{2}$ & 22 & 44 & \% & 26 & 52 \\
\hline LS2 & & 18 & 36 & 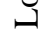 & 15 & 30 \\
\hline Total & & 50 & 100 & & 50 & 100 \\
\hline
\end{tabular}

Table 4 Nutritional level

\begin{tabular}{lccc}
\hline & & Frequency & Percentage $(\%)$ \\
UW & & 2 & 4 \\
NW & & 34 & 68 \\
OW & & 3 & 6 \\
OB & & 11 & 22 \\
Total & & 50 & 100 \\
\hline
\end{tabular}


The results of the Chi-square tests are shown in tables 5 and 6 indicate that there is no statistically significant difference or connection between the prevalence of kyphosis and the nutritional levels.

Table 5 Significance of the Chi square test for kyphosis and nutritional levels

\begin{tabular}{lccc}
\hline Chi-Square Tests & Value & df & Asymp. Sig. (2-sided) \\
\hline Pearson Chi-Square & $2.627^{\mathrm{a}}$ & 6 & .854 \\
Likelihood Ratio & 3.445 & 6 & .751 \\
Linear-by-Linear Association & .022 & 1 & .882 \\
N of Valid Cases & 50 & & \\
\hline
\end{tabular}

Table 6 Cross-section of the results between nutritional levels and kyphosis

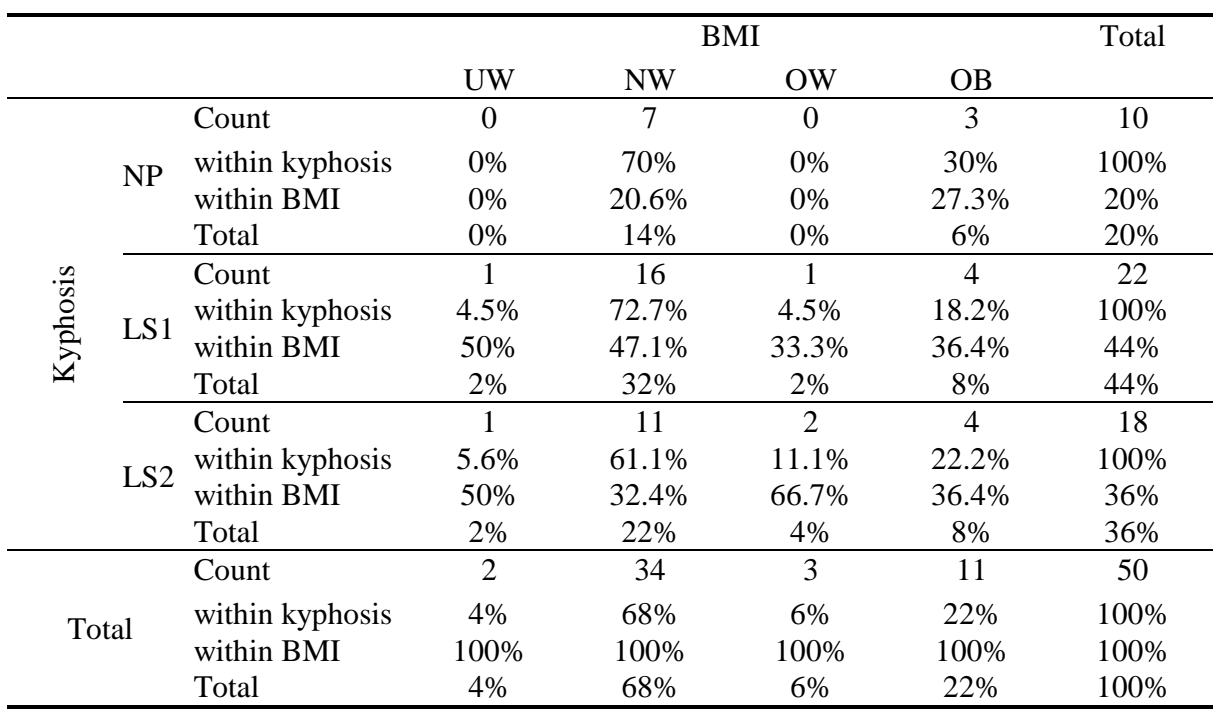

The results of the Chi square tests presented in tables 7 and 8 indicate that there is no statistically significant difference, that is, connection between the prevalence of lordosis and the nutritional levels.

Table 7 Significance of the Chi square test for lordosis and nutritional levels

\begin{tabular}{lccc}
\hline Chi-Square Tests & Value & df & Asymp. Sig. (2-sided) \\
\hline Pearson Chi-Square & $4.779^{\mathrm{a}}$ & 6 & .572 \\
Likelihood Ratio & 5.731 & 6 & .454 \\
Linear-by-Linear Association & .084 & 1 & .772 \\
N of Valid Cases & 50 & & \\
\hline
\end{tabular}


Table 8 Cross-section of the results between nutritional levels and lordosis

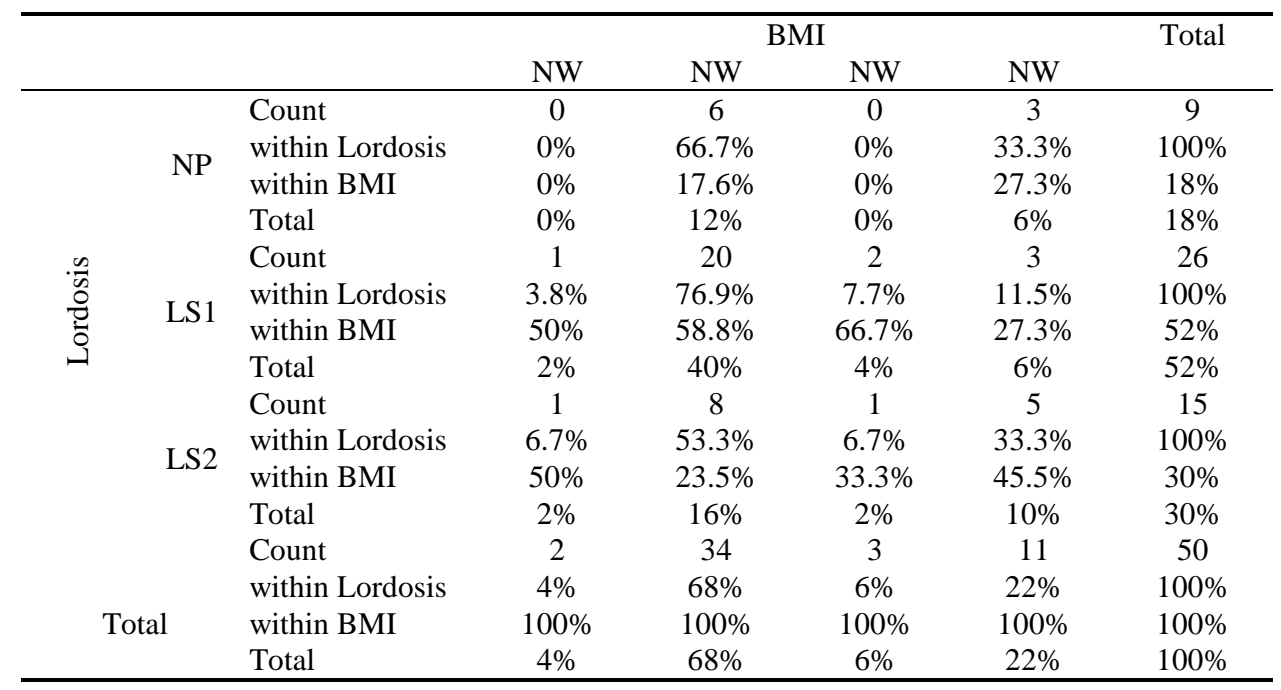

\section{DISCUSSION}

In the study, the percentage of obese children is as high as $22 \%$, which is greater than the values obtained in following two studies: Despotović et al. (2013) included preschool children residing on the territory of Ćuprija and determined a frequency of $5.4 \%$ of obese children, and $10.8 \%$ of overweight children. Stupar, Popović, and Vujović (2014), carried out study in four kindergartens on the territory of Novi Sad, and the percentage of overweight boys and girls was $8.62 \%$ and $7.61 \%$, respectively. Results more similar to our own were determined in the study of Đermanović, Miletić, and Pavlović (2015). Working with a sample of 60 children, they determined that $13.3 \%$ were overweight. In the case of preschool children, for a period of 20 years, more precisely from 1990 to 2010 the rate of obesity among children increased from $4.2 \%$ to $6.7 \%$. Additionaly, obesity among adults has increased dramatically since 1990 (De Onis, Blössner, \& Borghi, 2010). The increase in the number of obese preschool children requires more frequent measurements, so that adequate preventive measures could be realized.

The obtained results in terms of the prevalence of children with spine curvature disorders is disconcerting, since a large number of children with kyphosis and lordosis were identified. As many as $80 \%$ of children have kyphosis, and $82 \%$ lordosis of the first or second degree of severity. From the standpoint of the difficulty of correcting postural disorders, the good news is that a greater number of postural disorders of the first degree of severity can be corrected more effectively by applying appropriate corrective gymnastics exercises. Many children with spine curvature disorders of the same age as those in our sample were determined in the study (Simov, Minić, \& Stojanović, 2011). In their study $64 \%$ of children had some form of pine curvature disorder. In the study of Jorgic et al. (2015) the percentage of preschool children with spine curvature disorders in the sagittal plane such as kyphosis, lordosis and kyphosis-lordosis was $38.4 \%$. A study 
carried out among preschool children on the territory of three cities in west Serbia determined a prevalence of spine curvature disorders of $35.58 \%$ (Milenković, Živkovic, Milijić, Ignjatović, \& Pavlović, 2003). In the study of Hodžić, Gerdijan, Mikić, and Katanić, (2010) 53.6\% which included participants from the first to the fourth grade, it was determined that they showed signs of spine curvature disorders. In terms of percentages, the percentage of children with spine curvature disorders, or poor posture in this study was far greater the ones in other studies. The reason might be the different methodology of determining posture. What also speaks in favor of this conclusion is the fact that another study (Cvetković \& Perić, 2010) which included the same type of testing, identified a similar percentage of children with spine curvature disorders $(80.3 \%)$.

The results of this study indicate that there is no statistically significant connection between spine curvature disorders in the sagittal plane and the nutritional levels of the studied preschool children. Petrović et al. (2012) worked with a sample of 212 children aged 7 to 11 and also determined that the nutritional levels have no significant impact on the emergence of the spine curvature disorders. Kosinac and Ivačić (2009) determined that underweight has a strong connection with spine curvature disorders while obesity does not influence them. Đokić \& Stojanović (2010) determined that among children aged 9 to 12 obesity has an impact on lordosis, and only in the case of girls. Protić-Gava, Zečak, and Shukova-Stojmanovska, (2014) also determined that among children aged 7 and 8 there is no statistically significant correlation between physical deformity and nutritional levels.

For the insufficient correlations between spine curvature disorders in the sagittal plane (kyphosis and lordosis), on the one hand, and nutritional levels on the other, which is presented in this paper for a group of preschool children, there are several possible explanations. Namely, the preschool age is not significantly related to increased growth, which means that there is balanced development of the skeletal-muscle system. There is also the insufficiently long period of time during which obesity might act as a generator for the aforementioned disorders at this age, and thus this effect most probably had no significant impact on the status of the spinal column. The second possible explanation has to do with furniture, that is, the chairs and desks children use in preschool institutions, which are adapted to each age group, and therefore to a largest extent enable children to sit properly, unlike those meant for school age kids, who during class use furniture which is of inappropriate size (the same chairs and desks from grade one to grade eight). The third relevant explanation is the means of realizing the preliminary preschool program and the children's stay in preschool facilities. Namely, unlike school, in which children spend most of them time sitting at desks, or assuming passive stances during class, which is usually treated as the basic cause of the emergence of physical deformity, in preschool the educational program is realized through games, which to a great extent includes free movement of the children during the activity, and thus less hypokinesis and passive positions.

Based on the aforementioned, we could consider the effects of the nutritional levels on the postural status of preschool children to not be strongly expressed. It could be assumed that obesity and underweight can have an influence on the emergence of spine curvature disorders, but not independently, and instead in combination with other exogenic and endogenic factors such as heredity, physical inactivity, etc. 


\section{CONCLUSION}

The results of the current study indicated that nutritional levels have no statistically significant correlation with kyphosis and lordosis among preschool children. We can assume that obesity and underweight have no effect on the emergence of spine curvature disorders independently, but in combination with other exogenic and endogenic factors such as heredity, physical inactivity, etc. Considering that this study included a small sample of participants, it is necessary to carry out a study involving a larger sample of patricians, in order for the obtained results to be generalized.

\section{REFERENCES}

Cvetković, N., \& Perić, D. (2010). The Effects of specific games on the prevention of postural disorders in the sagittal plane in pre-school children, Sport Science \& Practice, 1(2) 145-159.

Cvetković, N. (2014). Vežboteka sa osnovama lokomotornog sistema i motornog učenja (An exercise book with the basics of the locomotor system and motor learning). Belgrade: Publik Praktikum. In Serbian

De Onis, M., Blössner, M., \& Borghi, E. (2010). Global prevalence and trends of overweight and obesity among preschool children. The American Journal of Clinical Nutrition, 92(5), 1257-1264.

Đermanović, M., Miletić, I., \& Pavlović, Z. (2015). Analysis of macronutrients intake and body mass index in preschool children in the western region of the Republic of Srpska. Srpski arhiv za celokupno lekarstvo, 143(11-12), 695-700.

Despotović, M., Alekxopulos, H., Despotović, M., \& Ilić, B. (2013). Stanje uhranjenosti dece predškolskog uzrasta (The nutritional levels of preschool children). Medicinski časopis, 47(2), 62-68. In Serbian

Đokić, Z., \& Stojanović, M. (2010). Morfološke karakteristike i posturalni status dece od 9 do 12 godina na području Sremske Mitrovice (The morphological characteristics and postural status of children aged 9 to 12 residing in the area of Sremska Mitrovica). Opšta medicina, 16(1-2), 41-49. In Serbian

Đorđević, S., Jorgić, B., Milenković, S., Milenković, M., Đokić, M., \& Tsonkova, D. (2016). Representation of kyphosis deformities in children of primary school in the republic of Serbia: a systematic review study. In: L.A. Velickovska (Ed). Conference proceedings of the 2nd International scientific conference Research in Physical Education, Sport and Health, (pp. 227-230). Skopje: Faculty of Physical Education, Sport and Health.

Garrow, J. S., \& Webster, J. (1985). Quetelet's index (W/H2) as a measure of fatness. International Journal of Obesity, 9(2), 147-153.

Hodžić, Z., Gerdijan, N., Mikić, B., \& Katanić, N. (2010). Posturalni poremećaji kičmenog stuba učenika od prvog do četvrtog razreda osnovne škole (Spinal curvature disorders among first to fourth grade elementary school children). Sportski logos, 8(14-15), 10-14. In Serbian

Jorgić, B., Milenković, M., Ždrale, S., Milenković, S., Stanković, R., \& Bubanj, S. (2015). Spinal cord posture in the sagittal plane among young schoolchildren residing in the area of Knjaževac. Facta Universitatis, Series Physical Education and Sport, 13 (2), 311-318.

Korovljev, D., Marinković, D., Roška, M., \& Madić, D. (2015). Posturalni status kičmenog stuba kod dečaka uzrasta od 4-13 godina (Postural status of the spinal column among boys aged 4-13). In: Z. Grgantov, S. Krstulović, J. Paušić, T. Bavčević, D. Čular, A. Kezić, \& A. Miletić (Eds.), Contemporary Kinesiology: 5th International Scientific Conference, (pp. 425-34). Split: Faculty of Kinesiology. In Serbian

Kosinac, Z., \& Ivačić, N. (2009). Relacije između nekih bitnih pokazatelja otklona posture i kifoze u djece mlađe životne dobi (Relations between certain indicators of the forward bend posture and kyphosis among younger children). In B. Neljak (Ed.). Proceedings of the 18. Summer School of Kinesiologist of the Republic of Croatia (pp. 154-160). Zagreb: Croatian Kinesiological Association. In Serbian

Kostić, Z., Gligorijević, S., \& Marković, L. (2001). Procena staturoponderalnog rasta dece uzrasta sedam godina u Nišu (An evaluation of the staturo-ponderal growth of children aged seven from the city of Niš). 40 Congress of Anthropological Society of Yugoslavia with international participation, Book of abstracts, (pp.73). Niš: Faculty of Medicine. In Serbian

Kuczmarski, R.J., Ogden, C.L., Guo, S.S., Grummer-Strawn, L.M., Flegal, K.M., Mei, Z., et al. (2002). 2000 CDC growth charts for the United States; Methods and development. Vital and health statistics. Series 11, Data from the national health survey, (246), 1-190. 
Marković, S., Igrutinović, Z., Kostić, G. \&, Vuletić, B. (2008). Stanje uhranjenosti i mogući činioci etiopatogeneze gojaznosti kod školske dece (Nutritional levels and possible factors of etiopathogenetics of obesity among school age children). Medicinski časopis, 1, 7-14. In Serbian

Milenković, S. (2007). Korektivna gimnastika teorija i vežbe (Corrective gymnastics: theory and practice). Niš: Faculty of Sport and Physical Education. In Serbian

Pavlović, S. (2012). Prisustvo telesnih deformiteta dece predškolskog uzrasta (Presence of body deformities at preschoolers). Univerzitetska misao, 11, 6-14. In Serbian

Milenković, S., Živković, D., Milijić, S., Ignjatović, I.., \& Pavlović Z. (2003). Status of the postural deformities and body deformities in younger school age children in communities Zaječar, Kruševac and Čačak. In: D. Živković (Ed.). Proceedings of the International Conference FIS Communications, (pp. 320-324). Niš: Faculty of Sport and Physical Education

Perić, D., \& Cvetković, N. (2003). Budi prav-bićeš zdrav (Stay upright-and you will keep health), Mladenovac: Kosmajturist. In Serbian

Petrović, J., Puzović, V., Đorđević, D., Obrenović, M., Medić, V., \& Jakovljević, V. (2012). Prevalenca deformiteta kičme kod dece uzrasta 7-11 godina [The prevalence of spinal curvature deformities among children aged 7 to 11.], Medicinski časopis, 46(4), 187-190. In Serbian

Protić-Gava, B., Šćepanović, T., \& Batez, M. (2013). Body posture at young schoolchildren in Novi Sad elementary school. Resaarch in Kinesiology, 41(2), 146-149.

Protić-Gava, B., Zečak, D., \& Shukova-Stojmanovska, D. (2014). The incidence of postural disorders with regard to degree of nutritional status in children from 7 to 10 years of age. Research in Physical Education, Sport and Health, 3(2), 77-82.

Simov, S., Minić, S., \& Stojanović, D. (2011). Učestalost pojave lošeg držanja tela i ravnih stopala kod dece predškolskog uzrasta. Apollinem medicum et aesculapium, 9(2), 5 - 8. In Serbian

Spiotta, R. T., \& Luma, G. B. (2008). Evaluating obesity and cardiovascular risk factors in children and adolescents. American Family Physician, 78(9), 1052-1058.

Steinberger, J., Daniels, S.R., Eckel, R. H., Hayman, L., Lustig, R.H., McCrindle, B., \& Mietus-Snyder, M.L. (2009). Progress and challenges in metabolic syndrome in children and adolescents. Circulation, 119(4), 628-647.

Stupar, D., Popović, B., \& Vujović, P. (2014). Stanje uhranjenosti predškolske dece Novog Sada [Nutritional level of preschool children from Novi Sad.]. Journal of the Anthropological Society of Serbia, 49, 51 - 55. In Serbian

Vlaški, J., \& Katanić, D. (2010). Zdravstveni i socijalni značaj epidemije gojaznosti kod adolescenata u Srbiji (The health and social significance of the obesity epidemic among adolescents in Serbia). Medicinski glasnik, 15(34), 43-46. In Serbian

Živković, D. (2009). Osnove kineziologije sa elemntima kliničke kineziologijen (An introduction to kinesiology with elements of clinical kinesiology). Niš: Faculty of Sport and Physical Education. In Serbian

\section{STEPEN UHRANJENOSTI I POSTURALNI POREMEĆAJI KIČMENOG STUBA DECE PREDŠKOLSKOG UZRASTA}

Savremeni načini života dovode do pojave hipokinezije, gojaznosti i različitih oboljenja i posturalnih poremećaja koji su prisutni sve više i kod dece najmlađeg uzrasta. Cilj ovog istraživanja je bio da se utvrdi povezanost stepena uhranjenosti sa kifotičnim i lordotičnim držanjem tela kod dece predškolskog uzrasta. Uzorak ispitanika činilo je 50 dečaka i devojčica predškolskog uzrasta od 6 do 7 godina koji pohađaju Predškolsku Ustanovu „Jelica Obradović“ u Mladenovcu. Za procenu telesne uhranjenosti korišćen je indeks telesne mase na osnovu čijih rezultta su ispitanici bili podenjeni u četiri kategorije: neuhranjeni, normalne težine, prekomerne težine i gojazni. Za procenu držanja tela koriščena je somatoskopija i testom telsnog držanja uz primenu drvenog rama sa mrežom sa kvadratnim decimetrima. Na osnovu rezultata ovog testa dobijene su sledeće varijable: normalno držanje, prvi stepen lošeg držanja i drugi stepen lošeg držanja. Za utvrđivanje povezanosti odnosno mogućeg uticaja stepena uhranjenosti na držanje tela korišćen je Hi kvadtrat test nezavisnosti. Rezultati istraživanja su pokazali da ne postoji statisitčki značajna povezanost između stepena uhranjenosti i kifotičkog i lordotičkog držanja tela kod ove grupe dece predškolskog uzrasta. To može ukazivati da gojaznost i neuhraenost nemaju uticaj na pojavu posturalnih poremećaja samostalno, već verovatno u kombinaciji sa ostalim faktorima kao što su nasledni, zatim fizička neaktivnost $i$ drugi.

Ključne reči: kifoza, lordoza, gojaznost, neuhranjenost, razlike 